\title{
Identifikasi, Keragaman dan Sebaran Caulerva sp Sebagai Komoditas Potensial Budidaya Pulau Bunguran, Natuna
}

\section{Identification, Diversity and Distribution of Caulerpa sp as Potential Commodities on Bunguran Island, Natuna}

\section{Tengku Said Razai ${ }^{1 *}$, Imam Pangestiansyah Putra ${ }^{2}$, Fadhliyah Idris ${ }^{3}$, Try Febrianto ${ }^{3}$, Muhammad Firdaus ${ }^{2}$.}

\footnotetext{
${ }^{1}$ Program Studi Budidaya Perairan, Universitas Maritim Raja Ali Haji, Tanjungpinang, Indonesia

${ }^{2}$ Laboratorium Oseanografi Kelautan, Universitas Maritim Raja Ali Haji, Tanjungpinang, Indonesia

${ }^{3}$ Program Studi Ilmu Kelautan, Universitas Maritim Raja Ali Haji, Tanjungpinang, Indonesia

*Koresponden: tengkusaidrazai@gmail.com
}

\begin{abstract}
Abstrak
Jenis angur laut Caulerpa sp saat ini menjadi komoditas ekspor sebagai produk makanan, obat-obatan, dan kosmetik. Caulerpa sp memiliki sebaran yang cukup luas terutama pada kawasan beriklim tropis. Jenis Caulerpa sp juga dijumpai hingga perairan Natuna. Kepulauan Natuna merupakan suatu wilayah di utara dari Provinsi Kepulauan Riau dengan potensi lautnya menyimpan sumberdaya yang beragam, termasuk komunitas anggur laut Caulerpa sp. Culerva sp merupakan salah satu jenis tumbuhan laut yang memiliki nilai nutrien yang baik tertutama untuk kesehatan dan kosmetik, sehingga penelitian terkait dengan sebaran jenis dan komposisinya sebagai upaya awal untuk pengembangan budidaya perlu dilakukan. Penelitian dilaksanakan selama periode bulan Juli-September 2019. Sampling dilakukan pada 8 lokasi yang berbeda mulai dari kawasan Ranai Kota hingga Klarik. Pengambilan data jenis Caulerpa sp mengunakan metode transek garis sepanjang 100 meter kearah laut dengan kuadran ukuran 10 x 10 m, sebanyak 3 kali sampling per stasiun. Hasil penelitian ditemukan 3 spesies dari anggur laut Caulerpa sp yakni C. taxifolia, C. lentilifera, dan C. recemosa. komposisi tertinggi pada jenis C.taxifolia mencapai $53,7 \%$. Hasil penelitian menunjukkan tingkat keanekaragaman yang rendah, keseragaman tergolong tinggi, dan dominansi yang rendah. Hanya ada beberapa stasiun dengan tingkat dominansi yang tinggi yakni stasiun 2 dan stasiun 6 masing-masing di dominasi oleh jenis $C$. taxifolia dan jenis C. lentilifera.
\end{abstract}

Kata kunci: Caulerva sp, Identifikasi, Keragaman, Sebaran

\begin{abstract}
.
The type of seawater Caulerpa sp is currently an export commodity as food products, medicines and cosmetics. Caulerpa sp has a fairly wide distribution, especially in tropical regions. Caulerpa sp species are also found in Natuna waters. Natuna Islands is an area in the north of the Riau Islands Province with the potential of the sea to store diverse resources, including the sea grape community Caulerpa sp. Culerva sp is one type of marine plant that has good nutritional value especially for health and cosmetics, so research related to the distribution of species and composition as an initial effort to develop aquaculture needs to be done. The study was conducted during the period July-September 2019. Sampling was carried out at 8 different locations ranging from the Ranai City area to Klarik. Retrieval of the Caulerpa sp type using the line transect method along 100 meters towards the sea with a quadrant measuring $10 \times 10 \mathrm{~m}$, as many as 3 times the sampling per station. The results found 3 species of sea grapes Caulerpa sp namely $C$. taxifolia, $C$. lentilifera, and $C$. recemosa. the highest composition in the type of $C$. taxifolia reached $53.7 \%$. The results showed a low level of diversity, high uniformity, and low dominance. There are only a few stations with a high level of dominance namely station 2 and station 6 each dominated by C. taxifolia types and C. lentilifera types.
\end{abstract}

Keywords: Caulerva sp, Identification, Diversity, Distribution 


\section{PENDAHULUAN}

Anggur laut Caulerpa sp kini menjadi komoditas potensi baru dalam dunia perikanan, budiaya jenis ini tengah gencar dilakukan dengan berbagai model pengembangan yang berbeda-beda. Bahkan jenis angur laut Caulerpa sp kini menjadi komoditas ekspor sebagai produk makanan, obat-obatan, kosmetik, dan produk lainya (Tanduyan et al., 2013). Anggur laut Caulerpa sp merupakan jenis alga laut hijau Chorophyta dengan kandungan asam amino dan protein, sehingga tengah dikembangkan menjadi produk unggulan (Nofiani et al. 2018). Jenis ini telah dikembangkan sebagai komoditas budidaya di Jepang dan Filiphina (Novianti et al., 2015).

Sebaran jenis Caulerpa sp cukup luas terutama pada kawasan beriklim tropis karena jenis ini membutuhkan asupan sinar matahari dalam proses fotosintesisnya. Jenis Caulerpa sp dijumpai di sebagian besar wilayah asia yakni; Indonesia, Thailand, Malaysia, Jepang, China, Filiphina, Korea, serta lokasi lain yang disekitar kawasan asia (Nofiani et al. 2018). Sebaran jenis Caulerpa sp juga dijumpai di pulau-pulau kecil di Indonesia. Jenis ini menyebar hingga kawasan timur Indonesia, perairan Maluku dan sekitarnya (Taputobun, 2018), serta Nusa Tengara (Oedjoe et al., 2019).

Kepulauan Natuna, merupakan suatu wilayah di utara dari Provinsi Kepulauan Riau dengan potensi lautnya menyimpan sumberdaya yang beragam. Termasuk pula ditemukanya jenis anggur laut yang tersebar sepanjang pantai pada zona pasang surut hingga tubir. Potensi pasar dan pengembangan budidaya jenis anggur laut Caulerpa sp sangat memungkinkan dilakukan di Kepulauan Natuna mengingat wilayah lautnya sangat mendukung untuk kegiatan tersebut. Pengembangan budidaya anggur laut Caulerpa sp akan memberikan kesempatan yang luas untuk berbagai usaha marikultur oleh masyarakat (Oedjoe et al., 2019).

Studi terkait dengan identifikasi jenis, sebaran jenis, keragaman, serta karakter habitat dari jenis anggur laut Caulerpa sp belum dilakukan di perairan Natuna. Pada dasarnya, studi terkait dengan kondisi tersebut merupakan bentuk informasi awal untuk pengembangan budidaya dan pengelolaan sumberdaya anggur laut Caulerpa $s p$ di perairan Natuna. Untuk itu, studi ini bertujuan untuk memberikan data awal terkait dengan jenis, komposisi, sebaran, serta keragaman jenis anggur laut Caulerpa sp yang dijumpai disekitar Pulau Bunguran, Natuna. 


\section{BAHAN DAN METODE}

Penelitian dilaksanakan selama periode bulan Juli-September 2019 tersebar disekitar Pulau Bunguran Natuna yang melibatkan 8 stasiun penelitian (Gambar 1.)

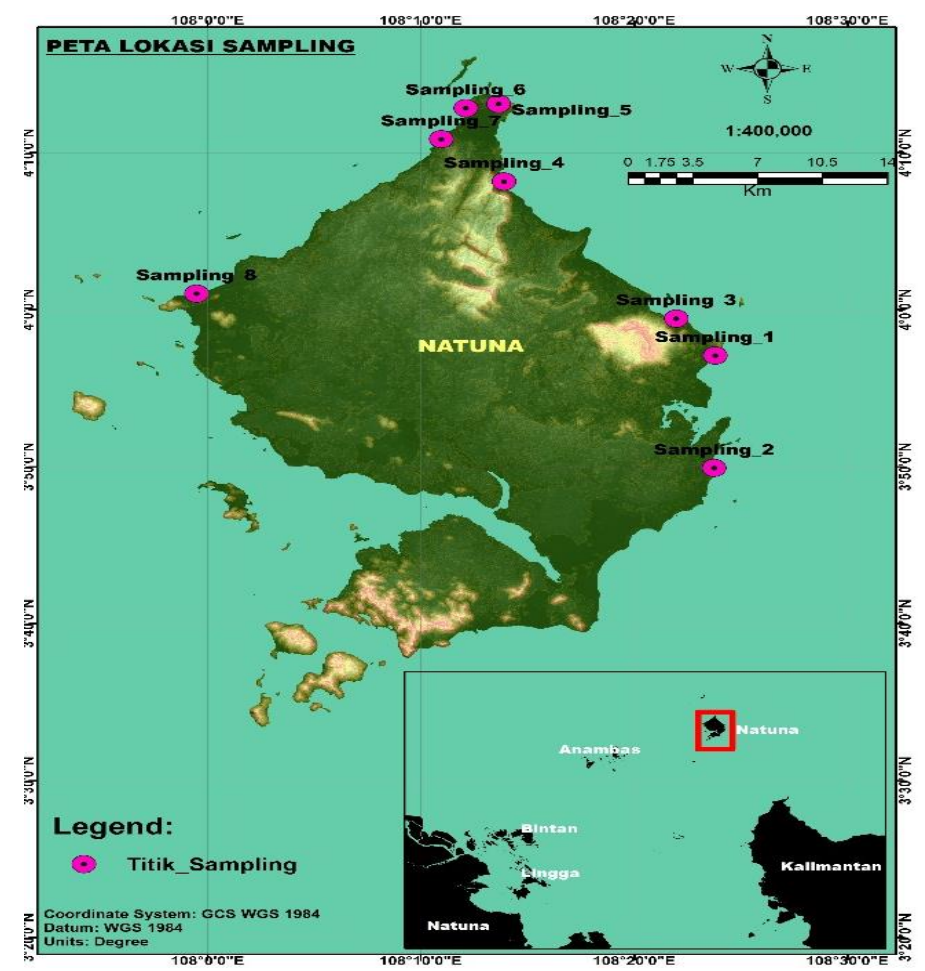

Gambar 1. Lokasi stasiun penelitian di Pulau Bunguran, Natuna

Sampling dilakukan pada 8 lokasi yang berbeda mulai dari kawasan Ranai Kota hingga Klarik. Pengambilan data jenis Caulerpa sp mengunakan metode transek garis (Litaay, 2014; Dwimayasari dan Kurnianto, 2018) sepanjang 100 meter kearah laut dengan kuadran (Ferawati et al., 2014) dengan ukuran 10 x 10 m, sebanyak 3 plot sampling per stasiun. Jenis anggur laut Caulerpa sp yang ditemukan, kemudian di identifikasi jenisnya, dihitung jumlah koloni per stasiun, diamati karakteristik habitatnya, serta diambil sampelnya ditambakan formalin $10 \%$ untuk identifikasi lebih lanjut. Pengolahan data anggur laut Caulerpa sp sebagai berikut;

\section{Komposisi Jenis}

Komposisi jenis dihitung berdasarkan jumlah koloni dan persentase setiap jenisnya dari masing-masing stasiun dengan mengunakan persamaan;

$$
K j(\%)=\frac{n}{n i} \times 100 \%
$$


Keterangan :

$\mathrm{Kj}=$ Komposisi jenis (\%); $\mathrm{n}=$ Jumlah individu suatu jenis (koloni); $\mathrm{ni}=$ Jumlah individu semua jenis (koloni)

\section{Keanekaragaman, Keseragaman, dan Dominansi Jenis}

Keanekaragaman jenis dihitung dengan mengunakan indeks keanekaragaman ShannonWiener (Fachrul, 2007);

$$
H^{\prime}=-\sum_{i=n}^{S}\left(\frac{n i}{N}\right) \ln \left(\frac{n i}{N}\right)
$$

Keterangan :

$\mathrm{H}^{\prime}$ = Keanekaragaman jenis; $\mathrm{ni}=$ Jumlah individu suatu jenis; $\mathrm{N}=$ Jumlah individu semua jenis; ln = Logaritme nature

Nilai indeks keanekaragaman di bagi menjadi 3 kondisi; jika nilai keanakaragaman lebih kecil dari 1 (rendah), jika nilai keanakaragaman lebih antara 1-3 (sedang), jika nilai keanakaragaman lebih besar dari 3 (tinggi).

Keseragaman jenis dihitung untuk melihat kemerataan jumlah antar spesies yang dijumpai menggunakan indeks Eveness-Pielou (Fachrul, 2007);

$$
E=\frac{H^{\prime}}{\ln s}
$$

Keterangan :

$\mathrm{E}=$ Indeks Keseragaman; $\mathrm{H}^{\prime}=$ Indeks Keanekaragaman; $\mathrm{s}=$ Jumlah jenis

Nilai indeks kemerataan berkisar antara 0-1, jika nilai indeks mendekati 0 artinya tidak ada kemerataan jenis yang ditemukan. Jika nilai indeks kemerataan mendekati 1 artinya terjadi kemerataan jenis yang dijumpai. Indeks ini dihitung untuk melihat terjadinya dominansi suatu jenis dalam suatu komunitas, indeks ini dihitung dengan menggunakan doninansi Simpson (Fachrul, 2007);

$$
D=\sum\left(\frac{n i}{N}\right)^{2}
$$

Keterangan :

$\mathrm{D}=$ Indeks Dominansi; $\mathrm{N}$ = Jumlah individu suatu jenis; $\mathrm{ni}=$ Jumlah individu semua jenis

Nilai indeks dominansi berkisar antara 0-1, jika nilai indeks mendekati 0 artinya tidak ada jenis yang mendominansi. Jika nilai indeks dominansi mendekati 1 artinya ada jenis yang mendominansi. 


\section{HASIL DAN PEMBAHASAN}

\section{Sebaran Jenis Anggur Laut Caulerpa spp di Pulau Bunguran, Natuna}

Berdasarkan pengamatan pada 8 stasiun penelitian di P. Bunguran, ditemukan 3 spesies dari anggur laut Caulerpa sp dengan sebaran yang berbeda antar stasiun. Jenis yang dijumpai di sekitar perairan P. Bunguran terdiri atas 3 spesies yakni Caulerpa taxifolia, Caulerpa lentilifera, dan Caulerpa recemosa (Gambar 2).
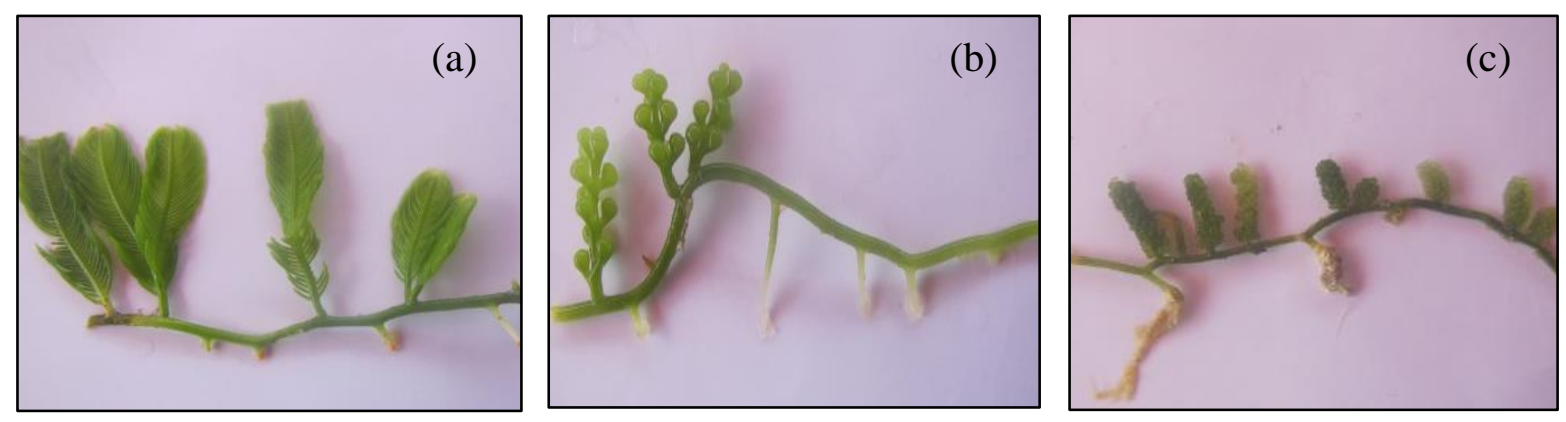

Gambar 2. Jenis anggur laut Caulerpa di perairan Natunaz: a) C. taxifolia, b) C. lentilifera, dan c) C. recemosa.

Jenis anggur laut Caulerpa yang terdapat diperairan Indonesia terdiri atas 5 spesies yakni C. lentilifera, C. taxifolia, C. racemosa, C. taxifolia, dan C. prolifera (Alvarez et al. (2012); Schembri et al. (2015); Masak et al. (2007). Sedangkan berdasarkan hasil penelitian yang dilakukan, jenis anggur laut Caulerpa sp yang di temukan di perairan P. Bunguran sebanyak 3 spesies dari total 5 spesies di Indonesia yakni jenis C. lentilifera, C.taxifolia, dan C. racemosa. Jenis-jenis anggur laut yang dijumpai cukup beragam dan sangat berpotensi untuk dikembangkan menjadi komoditas budidaya di perairan P. Bunguran. Pemanfaatan jenis anggur laut Caulerpa sp oleh masyarakat sekitar P. Bunguran sebagai makanan telah berlangsung lama, namun potensi pengembangan budidaya di wilayah tersebut belum dilakukan. Masyarakat cenderung masih mengekploitasi secara langsung di perairan. Menurut Tapotubun (2018) Caulerpa sp memiliki kandungan mineral, protein, karbohidrat dan serat kasar yang tinggi, tetapi kadar lemak rendah sehingga dapat dikembangkan sebagai makanan fungsional. Anggur laut Caulerpa sp yang dijumpai di perairan P. Bunguran memiliki sebaran jenis pada masing-masing stasiun. Tidak semua stasiun yang di sampling ditemui ketiga spesies tersebut, melainkan memiliki sebaran yang berbeda (Tabel 1.). 
Tabel 1. Sebaran jenis Anggur laut Caulerpa sp pada setiap stasiun penelitian

\begin{tabular}{lccc}
\hline \multicolumn{1}{c}{ Lokasi } & \multicolumn{3}{c}{ Jenis Anggur Laut } \\
\cline { 2 - 4 } & Caulerpa taxifolia & Caulerpa lentilifera & Caulerpa recemosa \\
\hline Batu Sindu (S1) & + & + & + \\
Ranai Kota (S2) & + & - & + \\
Batu Sindu (S3) & + & + & + \\
Desa Tanjung (S4) & + & + & - \\
Teluk Buton (S5) & + & + & - \\
Teluk Buton (S6) & + & + & + \\
Teluk Buton (S7) & + & - & + \\
Klarik (S8) & - & - & + \\
\hline
\end{tabular}

Keterangan : + (dijumpai); - (tidak dijumpai)

Sebaran jenis Anggur laut Caulerpa sp berbeda-beda pada stasiun penelitian. Jenis $C$. taxifolia hampir dijumpai pada semua stasiun, hanya pada stasiun 8 (Klarik) jenis ini tidak dijumpai. Jenis $C$. lentilifera sebarannya dijumpai pada stasiun 1 dan stasiun 3 (Batu Sindu, Ranai), Stasiun 4 (Desa Tanjung), Stasiun 5, 6, dan 7 (Teluk Buton). Sedangkan jenis $C$. recemosa ditemukan pada stasiun 1, Stasiun 2 (Ranai Kota), Stasiun 3, Stasiun 6, Stasiun 7, serta Stasiun 8. Secara keseluruhan jenis C. taxifolia merupakan jenis yang paling umum dijumpai di masing-masing stasiun penelitian. Sedangkan jenis $C$. lentilifera hanya dijumpai pada 5 stasiun dari 8 stasiun penelitian. Sebaran jenis anggur laut $C$. lentilifera sesuai dengan data komposisi jenis, jenis anggur laut yang paling banyak dijumpai pada stasiun penelitian memiliki komposisi jenis tertinggi dibandingkan dengan jenis lainnya.

Lokasi stasiun 1 dan Stasiun 3 (Batu Sindu), dan Stasiun 6 (Teluk Buton) merupakan stasiun yang dijumpai ketiga jenis anggur laut tersebut. Kondisi ini didukung oleh adanya paparan terumbu karang disekitar lokasi tersebut yang menjadi media penempelan akar holfast yang dimiliki oleh kelompok makro alga. Jika makro alga menempel pada jenis substrat keras, akan lebih kokoh terhadap arus dan gelombang. Seperti pernyataan Kadi (2004) bahwa kehadiran anggur laut di perairan Indonesia banyak dijumpai di perairan pantai yang mempunyai paparan terumbu. Sedangkan pada Stasiun 8 (Klarik) hanya dijumpai 1 jenis anggur laut yakni $C$. recemosa memiliki substrat lumpur, sehingga jika terjadi pengaruh arus dan gelombang menjadi lebih rentan.

Stasiun 8 (Klarik) hanya dijumpai 1 jenis anggur laut yakni C. recemosa. Diketahui pada lokasi ini kondisi substrat sedikit berlumpur dan perairan sedikit keruh. Namun jenis $C$. recemosa dapat hidup dan berkembang. Sedangkan jenis lainya dijumpai pada lokasi stasiun yang memiliki substrat lebih kasar dengan kondisi tipikal perairan yang lebih jernih. Menurut 
Litaay (2014) sebaran makro algae sangat berhubungan dengan tipe habitat dan dominasi jenis makro algae, termasuk pada karakteristik lokasi ditemukannya jenis ini.

\section{Komposisi Jenis Jenis Anggur Laut Caulerpa sp di Pulau Bunguran, Natuna}

Komposisi jenis anggur laut Caulerpa sp yang dijumpai di perairan P. Bunguran memiliki nilai persentase yang berbeda (Gambar 3)

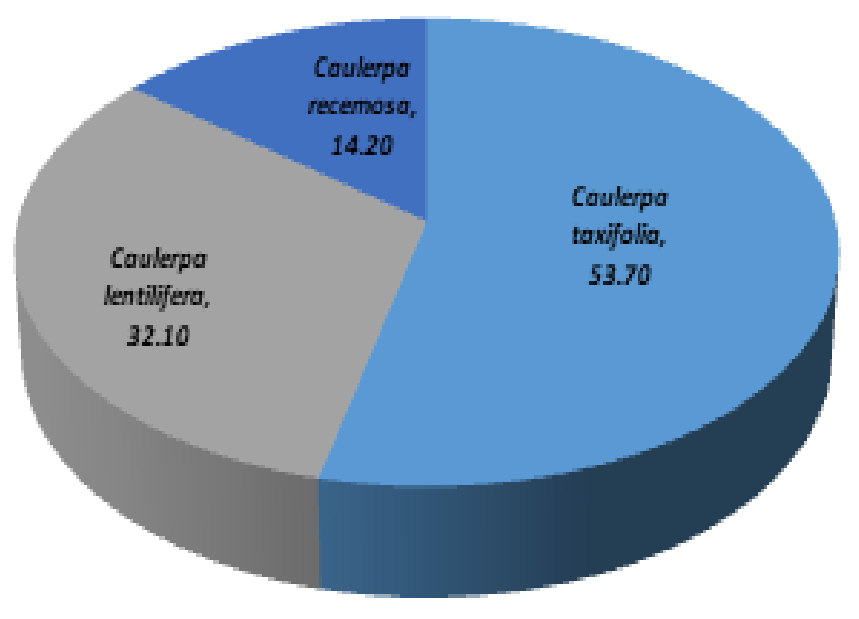

Gambar 3. Komposisi jenis anggur laut Caulerpa sp di P. Bunguran

Komposisi jenis C. taxifolia diketahui sebesar 53,70\% dan merupakan jenis dengan komposisi tertinggi. Jenis C. lentilifera memiliki komposisi sebesar 32,10\%, dan jenis Caulerpa recemosa komposisinya hanya sebesar 14,2\% dan merupakan yang terendah. Jenis anggur laut $C$. taxifolia merupakan jenis yang paling sering dijumpai di stasiun penelitian, dengan demikian komposisi jenis ini merupakan yang tertinggi dibandingkan kedua jenis lainnya. Faktor yang mempengaruhi tingginya komposisi jenis ini salah satunya yakni tipe habitat yang ditumbuhi oleh jenis $C$. taxifolia. Jenis ini dapat tumbuh pada berbagai macam tipe habitat (Tabel 2.)

Tabel 2. Tipe habitat jenis anggur laut Caulerpa sp

\begin{tabular}{lccc}
\hline \multicolumn{1}{c}{ Tipe Habitat } & C. taxifolia & C. lentilifera & C. recemosa \\
\hline Pecahan Karang dan Cangkang & + & + & + \\
Karang Mati & + & + & + \\
Karang Hidup & + & - & - \\
Pasir Kasar & + & + & + \\
Pasir Berlumpur & + & + & + \\
\hline
\end{tabular}

Keterangan : + (dijumpai); - (tidak dijumpai) 
Tipe habitat jenis anggur laut Caulerpa $s p$ diketahui bersubtrat pecahan karang dan cangkang, karang mati, karang hidup pasir karang, dan pasir halus/berlumpur. Jenis $C$. taxifolia dijumpai menempel pada pecahan karang dan bekas cangkang, karang mati, karang hidup, pasir kasar, dan pasir berlumpur. Sedangkan jenis C. lentilifera dan C. recemosa dijumpai tumbuh pada pecahan karang dan bekas cangkang, karang mati, pasir kasar, dan pasir berlumpur. Litaay (2014) menyatakan bahwa kebanyakan anggur laut berada di daerah tubir, menempel pada batu karang mati di daerah rataan terumbu atau pecahan karang bercampur pasir.

Kondisi anggur laut yang dijumpai di stasiun penelitian umumnya memiliki koloni yang melimpah pada substrat karang. Rumput laut yang menempel pada substrat karang lebih kokoh terhadap gangguan arus dan gelombang. Hal ini dijelaskan oleh Ferawati et al. (2014) makro alga lebih banyak menempel pada substrat karang dari pada substrat campuran dan substrat pasir. Substrat karang bersifat stabil sehingga rumput laut dapat melekat kuat sehingga tidak mudah terhempas pada saat golombang besar. Tanduyan et al. (2013) melakukan kultur jenis $C$. taxifolia dengan media tanam yang berbeda yakni lumpur, pasir, dan batu, hasil penelitian menunjukkan tingkat pertumbuhan $C$. taxifolia pada substrat berbatu lebih tinggi dan lebih rentan terhadap kondisi lingkungan.

\section{Keanekaragaman, Keseragaman, Dominansi Jenis Anggur Laut Caulerpa sp di Pulau Bunguran, Natuna}

Indeks keanekaragaman menggambarkan nilai keanekaragaman spesies anggur laut di perairan P. Bunguran. Nilai keanekaragaman yang tinggi mencirikan bahwa spesies yang dijumpai juga melimpah. Jika nilai keanekaragaman spesies rendah, menggambarkan jumlah spesies yang dijumpai di suatu lokasi juga sedikit. Hasil pengukuran indeks keanekaragaman anggur laut Caulerpa sp disajikan pada Tabel 3.

Tabel 3. Indeks Keanekaragaman Anggur Laut

\begin{tabular}{llc}
\hline \multicolumn{1}{c}{ Sampling } & \multicolumn{1}{c}{ Lokasi } & Keanekaragaman $\left(\mathbf{H}^{\prime}\right)$ \\
\hline Stasiun 1 & Batu Sindu & 0,98 \\
Stasiun 2 & Ranai Kota & 0,22 \\
Stasiun 3 & Batu Sindu & 0,76 \\
Stasiun 4 & Desa Tanjung & 0,55 \\
Stasiun 5 & Teluk Buton & 0,56 \\
Stasiun 6 & Teluk Buton & 0,53 \\
Stasiun 7 & Teluk Buton & 0,46 \\
Stasiun 8 & Klarik & 0,43 \\
\hline & Rata-rata & $\mathbf{0 , 5 6}$ \\
\hline
\end{tabular}


Indeks keanekaragaman jenis anggur laut Caulerpa sp di P. Bunguran berkisar antara 0,22-0,98 dengan kategori keanekaragaman kecil atau rendah. Artinya, nilai indeks menyebutkan bahwa anggur laut Caulerpa sp yang dijumpai tidak terlalu banyak spesiesnya. Teridentifikasi hanya dijumpai 3 spesies dari 5 spesies yang dilaporkan pernah dijumpai di Indonesia (Masak et al. 2007; Schembri et al. 2015; Alvarez et al. 2012; Ferawati et al. 2014; Wibowo et al. 2018). Diantara 8 stasiun sampling, stasiun 1 memiliki nilai keanekaragaman tertinggi (mendekati 1) mencirikan kestabilan komunitas anggur laut di stasiun tersebut lebih baik dibandingkan stasiun lainnya. Namun, untuk melihat kondisi komunitas anggur laut juga dilihat dari nilai indeks keseragaman (Tabel 4).

Tabel 4. Indeks Keseragaman Anggur Laut

\begin{tabular}{llc}
\hline \multicolumn{1}{c}{ Sampling } & \multicolumn{1}{c}{ Lokasi } & Keseragaman $(\mathbf{C})$ \\
\hline Stasiun 1 & Batu Sindu & 0,89 \\
Stasiun 2 & Ranai Kota & 0,32 \\
Stasiun 3 & Batu Sindu & 0,69 \\
Stasiun 4 & Desa Tanjung & 0,80 \\
Stasiun 5 & Teluk Buton & 0,80 \\
Stasiun 6 & Teluk Buton & 0,48 \\
Stasiun 7 & Teluk Buton & 0,66 \\
Stasiun 8 & Klarik & 0,63 \\
\hline & Rata-rata & $\mathbf{0 , 6 6}$ \\
\hline
\end{tabular}

Keseragaman spesies anggur laut di perairan P. Bunguran berkisar antara 0,32-0,89. Stasiun 1, stasiun 4, stasiun 5, memiliki tingkat keseragaman yang tinggi. Artinya, terdapat kemerataan jumlah dari masing-masing spesies. Sedangkan pada stasiun 3, stasiun 7, dan stasiun 8 kesegaraman jenis terkategori sedang yang mencirikan kemerataan antar spesies masih tergolong baik. Sedangkan pada stasiun 2 dan stasiun 6 memiliki nilai keseragaman yang rendah, artinya jumlah antar spesies anggur laut tidak merata. Indeks keseragaman yang rendah akan mencirikan adanya dominansi suatu spesies tertentu dalam komunitas anggur laut di P. Bunguran seperti tersaji pada Tabel 5.

Tabel 5. Indeks Dominansi Anggur Laut

\begin{tabular}{llc}
\hline \multicolumn{1}{c}{ Sampling } & \multicolumn{1}{c}{ Lokasi } & Dominansi (E) \\
\hline Stasiun 1 & Batu Sindu & 0,41 \\
Stasiun 2 & Ranai Kota & 1,00 \\
Stasiun 3 & Batu Sindu & 0,56 \\
Stasiun 4 & Desa Tanjung & 0,74 \\
Stasiun 5 & Teluk Buton & 0,42 \\
Stasiun 6 & Teluk Buton & 1,00 \\
Stasiun 7 & Teluk Buton & 0,04 \\
Stasiun 8 & Klarik & 0,07 \\
\hline & Rata-rata & $\mathbf{0 , 5 8}$ \\
\hline
\end{tabular}


Tabel 5. mengindikasikan bahwa nilai dominansi spesies angur laut berkisar antara 0,04-1,00. Stasiun dengan nilai dominansi yang tinggi yakni stasiun 2 dan stasiun 6 mencirikan adanya jumlah spesies yang dominan pada komunitas anggur laut. Dominansi spesies yang tinggi berbanding terbalik dengan indeks keseragaman, pada stasiun dengan nilai dominansi yang tinggi nilai keseragamanya akan lebih rendah. Pada stasiun 2 terjadi dominansi terhadap jenis $C$. taxifolia, sedangkan pada stasiun 6 terjadi dominansi jenis $C$. lentinifera. Namun secara keseluruhan nilai indeks dominansi diperoleh sebesar 0,58 yang mencirikan tingkat dominansi spesies untuk seluruh stasiun tergolong sedang.

\section{KESIMPULAN}

Pengamatan yang dilakukan pada 8 stasiun penelitian di P. Bunguran ditemukan 3 spesies dari anggur laut Caulerpa yakni C.taxifolia, C. lentilifera, dan C. recemosa. komposisi tertinggi pada jenis C. taxifolia mencapai 53,7\%. Hasil penelitian menunjukkan tingkat keanekaragaman yang rendah, keseragaman tergolong tinggi, dan tingkat dominansi yang rendah. Hanya ada beberapa stasiun dengan tingkat dominansi yang tinggi yakni stasiun 2 dan stasiun 6 masing-masing di dominasi oleh jenis $C$. taxifolia dan jenis C. lentilifera.

\section{REFERENSI}

Alvarez, E. V, Garreta. A. G, Lluch. J. R, Soler. N. S, Serrao. E. A, Siguan. M. A. R. 2012. Mediterranean Species of Caulerpa Are Polyploid with Smaller Genomes in the Invasive Ones. Plos One. 7(10): 1-11.

Dwimayasari. R dan Kurnianto. D. 2018. Komunitas Makroalga di Perairan Tayando-Tam, Maluku Tenggara. Oseanografi dan Limnologi di Indonesia. 3(1): 39-48.

Fachrul, M. F. 2007. Metode Sampling Bioekologi. Bumi Aksara, Jakarta.

Ferawati, E. Widyartini, D. S, Insan. I. 2014. Studi Komunitas Rumput Laut pada Berbagai Substrat di Perairan Pantai Permisan Kabupaten Cilacap. Scripta Biologica. 1(1): 5560 .

Kadi, A. 2004. Potensi Rumput Laut di Beberapa Perairan Pantai Indonesia. Oseana. 29(4): 25-36.

Litaay, C. 2014. Sebaran dan Keragaman Komunitas Makro Algae di Perairan Teluk Ambon. Jurnal Ilmu dan Teknologgi Kelautan Tropis. 6(1): 131-142. 
Nofiani, R. Hertanto. S, Zaharah. T. A, Gafur. S. 2018. Proximate Compositions and Biological Activities of Caulerpa lentillifera. Molekul. 13(2): 141-147.

Masak, P. R, Mansyur. A. Rachmansyah. 2007. Rumput Laut Jenis Caulerpa dan Peluang Budidayanya di Sulawesi Selatan. Media Akuakultur. 2(2): 80-85.

Novianti, D, Rejeki. S, Susilowati. T. 2015. Effect of Different Initial Weight to the Growth of Latoh (Caulerpa lentillifera) Cultivated at the Bottom of "Tambak", Jepara. Jurnal of Aquaculture Management and Technology. 4(4): 67-73.

Nurkiama, L, Muzahar, Idris. F. 2015. Keanekaragaman dan Pola Sebaran Makroalga di Perairan Laut Pulau Pucung Desa Malang Rapat Kabupaten Bintan. Repositori Jurnal UMRAH.

Oedjoe, M. D. R, Rebhung. F, Sunadji. 2019. Rumput Laut (Kappaphycus Alvarezii) sebagai Komoditas Unggulan dalam Meningkatkan Nilai Tambah Bagi Kesejahteraan Masyarakat Di Provinsi Nusa Tenggara Timur. Jurnal Ilmiah Perikanan dan Kelautan. 11(1): 62-69.

Schembri, P. J, Barbara. J, Deidun. A, Lanfranco. E, Lanfranco. S. 2015. It was only a matter of time: occurrence of Caulerpa taxifolia (Vahl) C. Agardh var. distichophylla (Sonder) Verlaque, Huisman and Procaccini in the Maltese Islands (Chlorophyta, Ulvophyceae, Caulerpaceae). Bio Invasions Record. 4(1): 9-16.

Tanduyan, S. N, Gonzaga. R. B, Bensig. V. D., 2013. Off bottom culture of Caulerpa lentillifera in three different water levels in the marine waters of San Francisco, Cebu, Philippines. Journal of Coral Reff Studies. 123-132.

Tapotubun, A. M. 2018. Komposisi Kimia Rumput Laut Caulerpa lentillifera dari Perairan Kei Maluku dengan Metode Pengeringan Berbeda. Jurnal PHPI. 21(1): 11-23.

Wibowo, E, Ario. R, Suryono, Taufiq. N, Destalino. 2018. Struktur Komunitas Rumput Laut di Perairan Pasir Panjang Desa Olibuu Kabupaten Boalemo, Gorontalo. Buletin Oseanografi Marina April. 7(1): 59-66. 